\title{
Büyük Menderes Havzasında Bazı Hidroklimatolojik Değișkenlerin Eğilim Analizi
}

\author{
Ödül ÖZTÜRK1,* \\ İlknur CEBECi' \\ 'Toprak Gübre ve Su Kaynakları Merkez Araștırma Enstitüsü Müdürlüğü, ANKARA
}

\begin{abstract}
*Sorumlu yazar e-mail (Corresponding author e-mail): odul.ozturk@tarimorman.gov.tr
Gelis tarihi (Received) : 29.07.2020

Kabul tarihi (Accepted): 23.10.2020

DOI: $10.21657 /$ topraksu.775654
\end{abstract}

\section{Öz}

İnsanlık tarihinden bu yana dünyanın değișen doğal dengesi, iklimleri de değiștirmektedir. Tüm canlı yașamı ve çevresini tehdit eden küresel iklim değișikliğinin su kaynaklarımız üzerinde de önemli etkiler yaratması muhtemeldir. Dolayısıyla hidroklimatolojik değișkenlerin zaman içerisindeki değișimlerini incelemek önem arz etmektedir. Bu çalıșmada Ege Bölgesinde yaklașık 26.000 km²'lik bir alan ile en büyük havza niteliğinde olan Büyük Menderes Havzası ele alınmıștır. Havzada yer alan Aydın, Denizli ve Ușak illerine ait uzun yıllar aylık ortalama yağıș, sıcaklık ve akım verileri Mann Kendall trend analizine tabii tutularak zaman içindeki değișim incelenmiștir. Buna göre sıcaklık bakımından en anlamlı artıș eğilimi yedi ay ile Denizli'de olurken Ușak'ta da yaz aylarındaki artıș istatistiksel olarak önemli bulunmuștur. Aydın ilinde ise sıcaklıklarda bir artıș söz konusu olup bu artıș istatistiki olarak önemli bulunmamıștır. Yağıș ve akım eğilimleri incelendiğinde ise Denizli ve Ușak'ta yağıșlarda görülen artıș eğilimi anlam teșkil etmez iken havzada bulunan iki akım istasyonunda da önemli azalıș eğilimi izlenmiștir.

Anahtar Kelimeler: Akım, Büyük Menderes Havzası, Mann Kendall, Sıcaklık, Yağıș

\section{Trend Analysis of Some Hydroclimatological Variables in Büyük Menderes Basin}

\begin{abstract}
At the beginning of the humanity, the changing natural balance of the world has also changed the climate. Global climate change, which threatens all life and its environment, is likely to have a significant impact on our water resources. It is therefore important to examine the precipitation and streamflow from the elements of the hydrological cycle as well as the changes in temperature in time. In this study, Büyük Menderes Basin, which is the largest basin of the Aegean Region with about $26.000 \mathrm{~km} 2$ area, was examined. In long-term average monthly precipitation, temperature and stream flow data belong to Aydın, Denizli and Ușak provinces which are taken up in the basin, were analyzed by using Mann Kendall Trend Analysis. Accordingly, while the most significant increase trend in temperature was in Denizli with seven months, the increase trend in summer months in Ușak was statistically significant, too. An increased trend was found in temperatures for Aydın, which was not statistically significant. When it comes to evaluate precipitation and streamflow trends; while increase trend was not found significant in Denizli and Ușak, significant decrease trend in stream flow was found in two stream gauging station in the basin.
\end{abstract}

Keywords: Flow, Büyük Menderes Basin, Mann Kendall, Precipitation, Temperature 


\section{Giriș}

İnsanlığın varolușundan bu yana dünyanın doğal dengesi değișmektedir. Bu doğal dengedeki değișimlerle iklimler de değișmektedir ancak 1850'li yıllardan itibaren insan etkisi de iklim değișikliğine hız kazandırmıștır. İklim değișikliği, sanayi devrimiyle bașlayan, giderek artan sanayileșme, fosil yakıtların kullanımı ve insan faktörüyle birlikte atmosferde karbondioksit birikmesi sonucu ortaya çıkan, günümüzün önemli sorunlarındandır. İklim değișikliği bugün hemen hemen tüm iklim bilimcilerin kabul ettiği ve insan faktörü katkısının yadsınmadığı bir kavramdır. Tüm canlı yașamı ve çevresini tehdit eden küresel iklim değișikliğinin, toprak ve su kaynaklarımız üzerinde de önemli etkiler yaratması muhtemeldir. Tarımsal üretimin de temelini olușturan ve insanlığın yașama kaynağı olan su kaynakları yașamın temel ögeleridir. Yağıș düzeninin ve sıcaklıkların değișmesi, su kaynakları üzerinde farklı etkiler gösterecektir. Yağıșın fazla olduğu alanlarda, șiddetli yağıșlar sebebiyle akarsuların debilerinde artma olacaktır. Yağıșın az olduğu alanlarda ise kuraklığın baș göstermesi ile buharlașma artacak ve kullanılabilir su miktarında azalma kaçınılmaz olacaktır. Çevrede olușacak bu değișiklikler toprakların kuraklașmasında en etkili faktör olarak rol alacaktır. Dolayısıyla değișen iklim bileșenleri ve akımlar arasındaki ilișki seyrinin izlenmesi ve bilinmesi oldukça önem arz etmektedir. Bu amaçla herhangi bir havzadaki meteorolojik bileșenlere ait verilerin doğru șekilde izlenmesi, incelenmesi ve analiz edilmesi ile akımlar arasındaki ilișkinin bilinmesi, su kaynaklarının etkin kullanımı için gereklilik haline gelmiștir. Gerçek șudur ki, su kaynakları planlaması ile ilgili yapılan çoğu çalıșmada iklim değișikliğinin etkilerine ya da yağıșlardaki değișimlere bağı olarak gözlenmiș verilerde eğilim gözlenmektedir. Gözlenen eğilimlerin niteliği ve bașlangıç tarihinin belirlenmesi havza yönetiminde yol gösterici olmaktadır (Çakmak ve Baran 2015).

Günümüze kadar küresel, bölgesel veya ülke ölçeğinde yapılmıș olan birçok iklim değișikliği çalıșması, iklim değișikliğinin akarsu havzaları üzerindeki potansiyel etkilerini yansıtmamaktadır. Bu nedenle belirli bir havzada iklim değișikliğinin olası etkilerini belirlemek ve bu etkileri yönetmek, havza bazında su kaynakıarını korumak adına büyük önem tașımaktadır (Chaponniere ve Smakhtin, 2006). Bu sebepledir ki, havza ölçeğinde, hidrolojik döngü ve su kaynakları üzerinde, iklim değișikliğinin etkilerini içeren araștırmalar artmaya bașlamıștır. Yapılan çalıșmalara göre Türkiye'yi kapsayan araștırmalarda, yıllık toplam yağıșlar ele alındığında genel olarak yağıșlarda bir azalma eğilimi bulunurken, bazı bölgelerde artıș eğilimi tespit edilmiștir (Türkeș, 1996; Türkeș ve ark., 2009; Partal ve Kahya, 2006; Özfidaner, 2007). Yıldırım ve ark. (2004), Gediz havzasındaki 4 akım gözlem istasyonu verilerini ve Akhisar meteoroloji istasyonu yağıș ölçümlerini kullanarak akım ve yağıș ilișkisini incelemișlerdir. Akhisar yağıș verileri eğiliminde kıș ayları hariç önemli bir değișim görülmez iken akım verilerinde su kullanımının da yoğun olduğu yaz mevsiminde önemli düșüș eğilimi saptanmıștır. Durdu (2010), Aydın, Denizli, Afyon ve Ușak istasyonlarında 45 yıllık iklim verilerini incelediği çalıșmasında sıcaklığın 45 yıllık sürede 1 OC yükseldiğini, yıllık toplam yağıșların azalma eğiliminde olduğunu ancak bu eğilimin istatiksel olarak önemli olmadığını tespit etmiștir. Büyük Menderes Nehrinin ana kollarında akım miktarları azalma eğilimi göstermiș olup bu eğilimin sıcaklık ve yağıșlardaki azalma ile güçlü bir bağlantısı olduğu vurgulanmıștır. Özkul (2009), Gediz ve Büyük Menderes Havzalarında yağıșların düșüș eğiliminde olduğunu Ancak Gediz havzasında sadece Menemen ve Manisa istasyonlarında, Büyük Menderes havzasında ise Aydın istasyonunda ki düșüș eğiliminin istatistiksel olarak anlamlı olduğunu belirtmiștir.

Kahya ve Kalaycı (2004), Türkiye' deki nehir akımlarının eğilim analizlerini inceleyerek, sıcaklık, nem ve yağıștaki değișimlerin akarsu rejimlerini de etkilediğini ve nehir akımlarında değișimlerin olduğunu ortaya koymușlardır. Cengiz ve Kahya (2006), Türkiye'nin yıllık ortalama göl seviye verilerine parametrik olmayan Mann Kendall istatistik trend testi uygulayarak daha önce yapılan akım, yağıș ve sıcaklık değișkenlerinin eğilimleriyle ilișkilendirmișlerdir. Bununsonucunda bahsigeçen değișkenler ile göl seviyelerinde ki eğilimlerin oldukça uyumlu olduğunu tespit etmișlerdir. Yağıș rejimleri ile göl su seviyelerinin, yersel ve iklimsel farklııklara rağmen birbirleri ile ilișkili olduğunu saptamıșlardır. Sonuç olarak bu eğilimlerin iklim değișikliğinin varlığını gösterdiğini belirtmișlerdir. Türkeș ve Deniz (2011), Güney Marmara'da yağıș ve akım serilerinin eğilim analizine göre 1980'lerin ortalarından bu yana yıllık yağıșlarda azalma 
eğilimi olduğunu, kıș aylarında ise 1970'lerden bu yana giderek belirginleșen bir azalma eğilimi saptamıșlardır. Araștırmacılar akarsulardaki akım verilerinden yararlanılarak iklim değișikliği/ değișkenliği konusunda önemli ipuçları elde edileceğini düșündükleri bu çalıșmada, akarsu akımlarında, 1990'lardan beri kıș mevsiminde belirgin bir azalma eğilimi belirlermișlerdir. Bahadır (2011), Kızılırmak Havzası'nı kapsayan çalıșmasında sıcaklık, yağıș ve akım eğilimlerini incelemiș, genel olarak sıcaklık ile akım arasında orta derecede negatif yönlü anlamlı ilișki, yağıș ile akım arasında pozitif yönlü orta derece anlamlı ilișki tespit etmiștir. Eğilim analizlerine göre, sıcaklığın uzun yıllık seyrinde artıș, yağıșta ise azalma, akım verilerinde ise tüm kollarda ve ana akarsuda azalma șeklinde gerçekleștiğini belirterek söz konusu eğilimlerin devam edeceği öngörüsüne sahip olmuștur.

Özkul ve ark.,(2008), küresel iklim değișikliğinin Gediz ve Büyük Menderes havzalarında akımlara olan etkisini inceledikleri çalıșmalarında, hidrometeorolojik verilerdeki eğilimleri araștırmıș ve sonrasında Genel Sirkülasyon Modelleri (GCM'ler) yardımıyla iki farklı emisyon senaryosu altında farkı projeksiyon yılları için olası yağıș ve sıcaklık değișimlerini belirleyerek bu değișen meteorolojik koșullar altında yüzeysel akımlardaki değișimleri saptamıșlardır. Eğilim analizlerine göre, Gediz havzasındaki yağıșların önemli ölçüde azaldığı, sıcaklıkların ise yine anlamlı düzeyde arttığı görülmüștür. Havza genelinde akım serilerinde istatistiksel olarak anlamlı düzeyde azalma eğilimi görülmüștür. Büyük Menderes havzasında ise yağıș verilerinde zamanla azalan bir eğilim gözlense de, istatistiksel olarak anlamlı bir azalma saptanamamıș; sıcaklıkta da anlamlı değișimler izlenmemiștir. Buna rağmen tarihsel akıș serileri ile yapılan eğilim analizlerinin sonuçları, yağıș ve sıcaklıkta istatistiksel açıdan anlamlı değișimler göstermemektedir. Akımlarda ise havza genelinde, istatistiksel olarak önemli ölçüde azalmalar olduğu belirlenmiștir.

Bu çalıșmada Büyük Menderes Havzası́nda yer alan Devlet Su İșleri (DSi)'ne ait akım gözlem istasyonlarından (AGi) elde edilen uzun yıllar aylık toplam akım verileri ve Meteoroloji Genel Müdürlüğü (MGM)'ne ait meteoroloji gözlem istasyonlarından (MGi) uzun yıllar aylık ortalama sıcaklık ve yağıș verileri alınarak eğilim analizleri yapılmıștır.

\section{MATERYAL VE YÖNTEM}

\section{Havzaya ait genel bilgiler}

Büyük Menderes Havzası Ege Bölgesinde yer alan en büyük havza olmakla birlikte havzanın bașlıca akarsuyu 584 km uzunluğu ile Büyük Menderes Nehri ve kollarıdır. Nehrin önemli kolları Çine, Akçay, Emir, Banaz, Kufi, Dandalaz ve Madran Çaylarıdır. Büyük Menderes Havzası sınırları içerisinde Afyonkarahisar, Aydın, Burdur, Denizli, Isparta, İzmir, Kütahya, Manisa, Muğla ve Ușak olmak üzere 10 il yer almaktadır. Havzada yer alan illerin alansal dağılımı Șekil 1'de verilmiștir. Șekil 1 incelendiğinde Aydın, Denizli ve Ușak illerinin havzanın büyük bir kısmını olușturduğu görülmektedir.

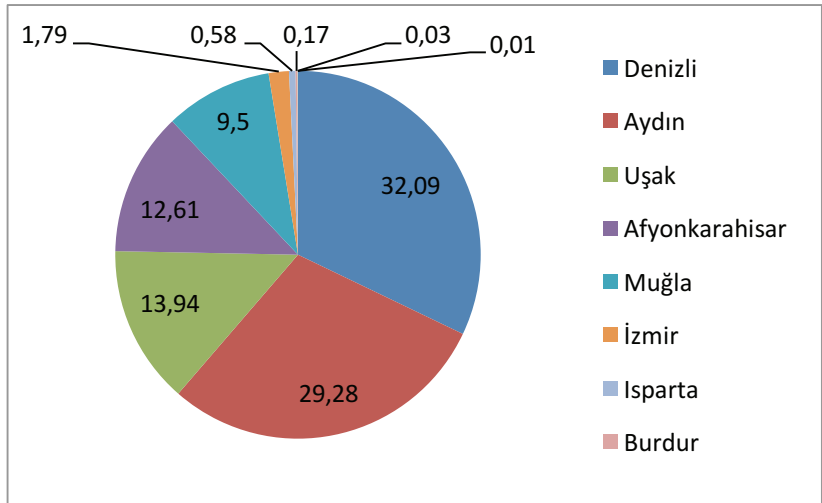

Șekil 1. Havzada yer alan illerin alansal dağılımı (Anonim, 2010)

Figure 1. Area distribution of the provinces in the basin

Büyük Menderes havzası Batı Anadolu'da, $37^{\circ} 6^{\prime}-38^{\circ} 55^{\prime}$ kuzey enlemleri ile $27^{\circ} 15^{\prime}$ - $30^{\circ}$ 36' doğu boylamları arasında yer almaktadır. Havzanın güneyinde ve batısında Akdeniz iklimi hakim olup, kıșları ılık ve yağıșlı, yazları sıcak ve kurak; kuzeyinde ise karasal iklim hakim olup kıșları soğuk ve yağıșlı geçmektedir. Havzanın uzun yıllar

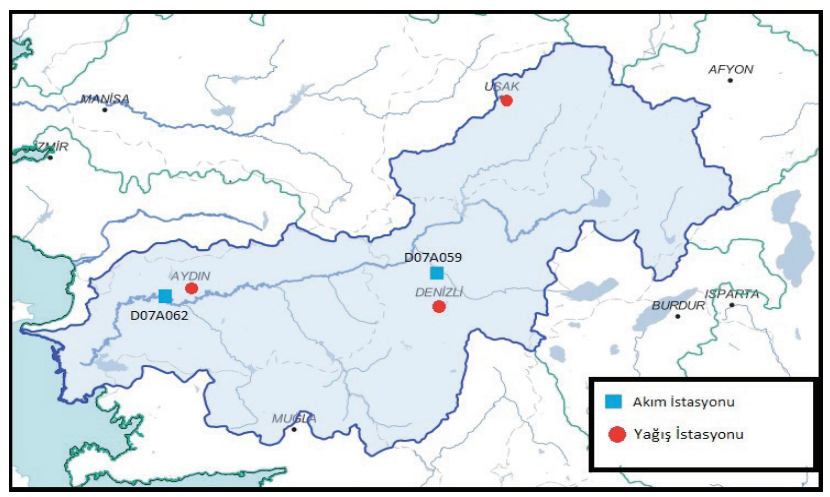

Șekil 2. Büyük Menderes Havzasının Konumu ve İstasyonlar Figure 2. Location of the Büyük Menderes basin and stations 
Çizelge 1. Büyük Menderes havzasındaki istasyonlara ait bazı bilgiler

Table 1. Some information from stations in the Büyük Menderes basin

\begin{tabular}{ccccccc}
\hline \multirow{2}{*}{ istasyon Adı } & \multirow{2}{*}{ istasyon No } & \multirow{2}{*}{ Enlem } & \multirow{2}{*}{ Boylam } & Rakım $(\mathrm{m})$ & \multicolumn{2}{c}{ Veri Aralığı } \\
\cline { 6 - 7 } Aydın MGi & 17234 & 37.51 & 27.51 & 56 & $1950-2016$ & Sıcaklık \\
Denizli MGi & 17237 & 37.47 & 29.05 & 426 & $1957-2016$ & $1957-2016$ \\
Ușak MGi & 17188 & 38.41 & 29.24 & 919 & $1950-2014$ & $1950-2016$ \\
\hline İstasyon Adı & İstasyon No & \multirow{2}{*}{ Enlem } & \multirow{2}{*}{ Boylam } & Rakım (m) & Veri Aralığı \\
\hline Aydın/Koçarlı AGi & D07A062 & 29.4 & 37.55 & 17 & Akım \\
Denizli/Çürüksu AGi & D07A059 & 27.43 & 37.49 & 160 & $1968-2015$ \\
\hline
\end{tabular}

yağıș ortalaması 635 mm'dir. Ortalama yıllık yağıș havzanın doğusunda 350 mm'ye kadar düșmesine rağmen kıyı kesimlerine doğru artmakta, özellikle güneydeki dağlık alanlarda 1000 mm'yi așmaktadır (Yeșilırmak ve ark., 2011). Havzanın nüfusu yaklașık 2.5 milyon olup havzada bulunan suyun \%79'u tarımsal ve \%21'i endüstriyel+evsel amaçlı olarak kullanılmaktadır (Anonim, 2016).

Yapılan bu çalıșmada yaklașık 26.000 km2'lik alanıyla Ege Bölgesi'nin en büyük havzası olan Büyük Menderes Havzası ele alınmıștır. Havzada yer alan ve havza alanının \%75'ini olușturan Aydın, Denizli ve Ușak illerine ait, sırasıyla 67, 60 ve 65 yıllık, aylık toplam yağıș ortalaması ve aylık ortalama sıcaklık verileri kullanılmıștır. Denizli ili sınırlarında yer alan Cürüksu AGi'den 30 yıllık, Aydın ili sınırlarında yer alan Koçarlı AGi'den ise 47 yıllık akım verileri temin edilmiștir. Büyük Menderes Havzasının konumu ve havzada yer alan MGM ve DSi'nin ișlettiği istasyonlar Șekil 2'de gösterilmiștir. Verilerin elde edildiği bu istasyonlara ait bazı veriler Çizelge 1' de verilmiștir. Söz konusu istasyonlara ait uzun yıllar aylık toplam yağıș, ortalama sıcaklık ve toplam akım verileri Mann Kendall trend analizine tabii tutularak zaman içindeki değișimleri incelenmiștir.

\section{Mann-Kendall sıra korelasyon testi}

Mann-Kendall, parametrik olmayan sıra korelasyon testi olup hidrometeorolojik zaman serilerinde meydana gelebilecek artma veya azalma yönündeki eğilimlerin istatistiksel önemini test etmede oldukça yaygın kullanılmaktadır (Yue, Wang, 2002). Bu eğilim testi $i=1, \ldots, n-1$ 'e kadar sıralanmıș olan bir xi veri setine ve $j=i+1, \ldots$, n'e kadar sıralanmıș olan bir xj veri setine uygulanır. Her bir sıralanmıș rakam xi bir referans noktası olarak kullanılır ve diğer sıralanmıș veri grubu xj ile așağıdaki denklemde verildiği gibi kıyaslanır.
$\operatorname{sgn}\left(X_{j}-x\right)=\left\{\begin{array}{c}1 ;\left(X_{j}-x\right) \\ 0 ;\left(X_{j}-x\right) \\ -1 ;\left(X_{j}-x\right)\end{array}\right.$

Mann- Kendall test istatistiği S ise;

$S=\sum_{i=1}^{n-1 n} \sum_{j+1} \operatorname{sgn}\left(x_{j}-x\right)$

formülü ile belirlenebilir. Denklemde $n$, yıl olarak veri uzunluğudur. $S$ değeri ise $n \geq 8$ olduğunda așağıda verilen ortalama ve varyans ile yaklașık olarak normal dağıım gösterir. Eğer $n \geq 30$ ise $z$ testi, t-testine yaklașır (Çakmak ve Baran,2015).

$E[S]=0$

$\operatorname{Var}(S)=\frac{\mathrm{n}(\mathrm{n}-1)(2 \mathrm{n}+5)-\sum t_{i}\left(t_{i}^{-1}\right)\left(2 t_{i}+5\right)}{18}$

Burada, p veri setindeki tekrar gözlem sayılarını, ti değeri ise i uzunluğundaki bir ${ }^{\mathcal{s}}$ seride tekrarlanan gözlemleri göstermektedir. Eșitlikteki toplama terimi sadece veride bağlı gözlem olduğunda kullanılır. Standartlaștırılmıș Mann-Kendall istatistiği Z, denklem (4)'de verildiği gibi hesaplanabilmekte ve seride eğilim yoktur sıfır hipotezi ( HO ) varsayımı altında ortalaması sıfır, varyansı bir olan standart normal dağılım göstermektedir.

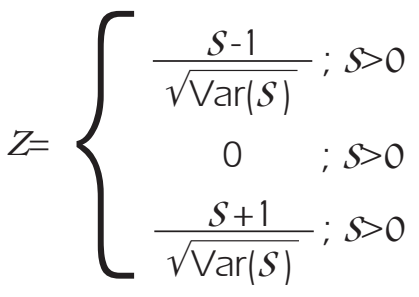

Mann Kendall test istatistiği ZZtablo , 1- $\alpha / 2 \leq Z \leq$ Ztablo, 1- $\alpha / 2$ ise, "sıfır hipotezi" kabul edilmektedir. 
Artı Z değeri artan bir eğilimi gösterirken, eksi Z değeri azalan bir eğilime ișaret etmektedir (Yue ve ark., 1993).

Parametrik ve parametrik olmayan test istatistikleri, istatiksel olarak anlamlı eğilimlerin belirlenmesi için kullanılmaktadır. Ancak parametrik testler normal dağılıma uyma, lineerlik sağlama gibi șartlar gerektirdiğinden hidroklimatolojik veri serilerinde kullanıșlı değildir. Bunun yanında parametrik olmayan test istatistikleri, değișkenin dağılımından bağımsız olması ve testlerinin sıra ile ilgili olmasından dolayı daha kullanıșlı olmaktadır. Parametrik olmayan test istatistikleri eksik veri ve kısıtlı veri sayısını tolere edebildiği için tercih nedeni olmaktadır.

Mann Kendall test istatistiği, hidroloji ve klimatoloji gibi alanlardaki zaman serilerinde eğilimin belirlenmesinde yaygın olarak kullanılan ve Dünya Meteoroloji Örgütü (WMO) tarafından da önerilen bir yöntemdir (Kosif, 2001).Türkiye'de ve dünyada Erdoğan (1989), Toros (1993), İçağa (1994), Türkeș (1996), Kadıoğlu (1997), Kalaycı ve Kahya (1998), Kosif (2001), Zhang ve ark.,(2001) Burn ve Elnur (2002), Özel (2004), Kahya ve Kalaycı (2004), Sütgibi (2009), Durdu (2010), Çakmak ve Baran (2015) tarafından bu yöntem kullanılarak eğilim analizi çalıșması yapılmıș ve Mann Kendall testinin bașarısı ortaya konulmuștur.

\section{BULGULAR VE TARTIȘMA}

Havzadaki 3 adet meteoroloji gözlem istasyonunda (MGi) ölçülen uzun yıllar aylık toplam yağıș ve uzun yıllar aylık ortalama sıcaklık verileri ile 2 adet akım gözlem istasyonundan (AGi) elde edilen uzun yıllar aylık toplam akım verilerinin eğilimlerini belirlemek için kullanılan parametrik olmayan Mann Kendall testinin sonuçları Çizelge 2,3,4'te verilmiș ve eğilimlerle ilgili genel bir değerlendirme yapılmıștır. Çizelgelerde yıldızlı koyu renkli alanlar herhangi bir yönde istatistiki anlam tașıyan sonuçları göstermektedir.

Test istatistiğinin mutlak değerinin, 0.05 olarak alınan $\alpha$ anlamlılı seviyesindeki Z değerinin (+) 1.96 ve (-) 1.96 aralığında olması herhangi bir eğilimin olmadığını göstermekte olup, Z değerinin (+) 1.96' dan büyük olması istatistiki olarak artan yönde eğilim ve (-) 1.96 değerinden küçük olması ise azalan yönde eğilim olduğunu göstermektedir

Buna göre Çizelge 2'de havzanın sıcaklık eğilimleri incelendiğinde özellikle Denizli ve Ușak istasyonlarında önemli düzeyde artıș eğilimi görülmekte olup Denizli istasyonunda Nisan-

Çizelge 2. Uzun Yıllar Aylık Ort. Sıcaklık Verilerinin Eğilim Sonuçları

Table 2. Trend Results of Monthly Average Temperature Data for Many Years

\begin{tabular}{|c|c|c|c|c|c|c|}
\hline \multirow{5}{*}{ Aylar } & \multirow[b]{2}{*}{ İstasyon Adı: } & \multirow[b]{2}{*}{ Denizli } & \multicolumn{2}{|c|}{ Sicaklık } & \multirow[b]{2}{*}{ İstasyon Adı: } & \multirow[b]{2}{*}{ Aydın } \\
\hline & & & \multirow{2}{*}{$\begin{array}{l}\text { İstasyon Adı: } \\
\text { İstasyon No: }\end{array}$} & Ușak & & \\
\hline & İstasyon No: & 17237 & & 17188 & İstasyon No: & 17234 \\
\hline & Veri Aralığı: & $1957-2016$ & Veri Aralığı: & $1950-2016$ & Veri Aralığı: & $1950-2016$ \\
\hline & Test Z & Eğilim & Test Z & Eğilim & Test $\mathbf{Z}$ & Eğilim \\
\hline 1 & 1.15 & $\uparrow$ & 0.30 & $\uparrow$ & -0.17 & $\downarrow$ \\
\hline 2 & 1.23 & $\uparrow$ & 0.67 & $\uparrow$ & -0.14 & $\downarrow$ \\
\hline 3 & 1.76 & $\uparrow$ & 1.24 & $\uparrow$ & 0.98 & $\uparrow$ \\
\hline 4 & 1.97 & $* \uparrow$ & 0.35 & $\uparrow$ & 0.82 & $\uparrow$ \\
\hline 5 & 2.86 & $* \uparrow$ & 1.45 & $\uparrow$ & 1.59 & $\uparrow$ \\
\hline 6 & 4.41 & $* \uparrow$ & 2.26 & $* \uparrow$ & 1.94 & $\uparrow$ \\
\hline 7 & 5.44 & $* \uparrow$ & 2.65 & $* \uparrow$ & 1.93 & $\uparrow$ \\
\hline 8 & 5.14 & $* \uparrow$ & 1.99 & $* \uparrow$ & 1.51 & $\uparrow$ \\
\hline 9 & 4.68 & $* \uparrow$ & 1.12 & $\uparrow$ & 0.95 & $\uparrow$ \\
\hline 10 & 2.16 & $* \uparrow$ & 1.47 & $\uparrow$ & 1.06 & $\uparrow$ \\
\hline 11 & 0.61 & $\uparrow$ & 0.33 & $\uparrow$ & -0.49 & $\downarrow$ \\
\hline 12 & -0.71 & $\downarrow$ & -0.65 & $\downarrow$ & -1.35 & $\downarrow$ \\
\hline \multicolumn{7}{|c|}{ * \%95 güven aralığında önemli eğilim } \\
\hline \multicolumn{3}{|c|}{ ^ Artma Yönünde Eğilim } & & \multicolumn{3}{|c|}{$\downarrow$ Azalma Yönünde Eğilim } \\
\hline
\end{tabular}


Ekim arasındaki artıș eğilimi istatistiki anlamda $(\alpha=0.05)$ önemli görülmüștür. Ușak istasyonunda ise Haziran, Temmuz ve Ağustos aylarında istatistiki olarak önemli artıș eğilimi görülmektedir. Denizli ve Ușak istasyonlarında azalma yönünde eğilim sadece Aralık ayında olup istatistiki açıdan önem teșkil etmemektedir. Aydın istasyonunda kıș mevsimi aylarında sıcaklıklarda azalma yönünde eğilim görülürken diğer aylarda görülen sıcaklık artıș eğilimi istatistiki olarak anlam tașımamaktadır (Çizelge 2). Sütgibi (2009)'dan farklı olarak, farklı zaman serilerinde ve uzun yıllar aylık ortalama sıcaklık verileri üzerinden yaptığımız çalıșmamızın sonucu, Sütgibi (2009)'un incelediği farklı zaman serilerinde uzun yıllar günlük ortalama, maksimum ve minimum sıcaklıklara ait eğilim sonuçları araștırmamızı destekler niteliktedir. Sütgibi (2009), havzadaki dört istasyonda sıcaklıkların, yıllar itibariyle değișim ve artıș gösterdiğini bulmuștur. Aydın, Denizli ve Ușak'ta bu artıș eğilimini \%95 $(\alpha=0,05)$ olasılıkla anlamlı bulmuștur.

Yağıș eğilim çizelgesi incelendiğinde ise araștırmaya konu olan üç istasyonda da kıș, yaz ve sonbahar aylarında yağıșlarda \%95 güven aralığında anlamlı olmayan azalma ve artma eğilimi görülmektedir. Sadece Ușak ilinde nisan ayı yağıșlarında anlamlı artıș eğilimi belirlenmiștir
(Çizelge 3). Koçman ve ark. (1996), 48 yıllık bir zaman serisinde, Ege ovalarındaki yağıș rejimini ve miktarındaki değișimi incelemiștir. Koçman ve ark. (1996), çalıșmalarında yağıș miktarında yıldan yıla önemli değișiklikler tespit etmesine rağmen istatiksel anlam tașıyan bir azalma veya artma eğilimi bulamamıștır. Bu bulgular araștırmamızın sonucunu destekler niteliktedir. Sütgibi (2009), uzun yıllar günlük toplam yağıșlar üzerinden yaptığı eğilim analizinde çalıșmaya konu olan dört istasyonda da yağıș miktarında istatistiki anlam tașıyan herhangi bir eğilim bulamamaıștır. Bulgular araștırmamızın sonuçları ile örtüșmektedir. Benzer șekilde Durdu (2010), Büyük Menderes Havzasında Aydın, Denizli, Afyon ve Ușak istasyonlarında 1963- 2007 yılları arasında kaydedilen yıllık toplam yağıș serilerinin eğilimlerini parametrik (t-testi) ve parametrik olmayan (Mann-Kendall) testi ile incelediği çalıșmasında yağıșların azalma eğiliminde olduğunu ancak eğilimin anlamlı olmadığını saptamıștır. Özkul (2009), Pearson ve Spearman test istatiskleri ile yaptığı analizde yıllık toplam yağıșların azalma eğiliminde olduğunu fakat eğilimin sadece Aydın istasyonunda anlamlı olduğunu bulmuștur. Bir diğer sonuç Partal ve Kahya (2006) tarafından Türkiye genelinde 96 istasyona ait aylık toplam yağıș ve yıllık ortalama

Çizelge 3. Uzun Yıllar Aylık Toplam Yağıș Verilerinin Eğilim Sonuçları

Table 3. Trend Results of Monthly Average Precipitation Data for Many Years

\begin{tabular}{|c|c|c|c|c|c|c|}
\hline \multirow{5}{*}{ Aylar } & & & \multicolumn{2}{|c|}{ Yağıș } & \multirow[b]{2}{*}{ İstasyon Adı: } & \multirow[b]{2}{*}{ Aydın } \\
\hline & İstasyon Adı: & Denizli & \multirow{2}{*}{$\begin{array}{l}\text { İstasyon Adı: } \\
\text { İstasyon No: }\end{array}$} & Ușak & & \\
\hline & İstasyon No: & 17237 & & 17188 & İstasyon No: & 17234 \\
\hline & Veri Aralığı: & $1957-2016$ & Veri Aralığı & $1950-2014$ & Veri Aralığı & $1950-2016$ \\
\hline & Test Z & Eğilim & Test Z & Eğilim & Test Z & Eğilim \\
\hline 1 & -0.26 & $\downarrow$ & -0.67 & $\downarrow$ & -0.69 & $\downarrow$ \\
\hline 2 & 0.97 & $\uparrow$ & -0.24 & $\downarrow$ & -0.74 & $\downarrow$ \\
\hline 3 & -0.08 & $\downarrow$ & -0.65 & $\downarrow$ & 0.38 & $\uparrow$ \\
\hline 4 & 0.70 & $\uparrow$ & 2.05 & $* \uparrow$ & 0.63 & $\uparrow$ \\
\hline 5 & 0.81 & $\uparrow$ & -0.71 & $\downarrow$ & 0.27 & $\uparrow$ \\
\hline 6 & -0.43 & $\downarrow$ & -0.79 & $\downarrow$ & -0.18 & $\downarrow$ \\
\hline 7 & 0.11 & $\uparrow$ & -0.01 & $\downarrow$ & -1.27 & $\downarrow$ \\
\hline 8 & 0.71 & $\uparrow$ & 0.78 & $\uparrow$ & -0.84 & $\downarrow$ \\
\hline 9 & -0.38 & $\downarrow$ & -0.23 & $\downarrow$ & -0.87 & $\downarrow$ \\
\hline 10 & 0.78 & $\uparrow$ & 1.92 & $\uparrow$ & 0.32 & $\uparrow$ \\
\hline 11 & 1.14 & $\uparrow$ & 0.29 & $\uparrow$ & 0.09 & $\uparrow$ \\
\hline 12 & -1.86 & $\downarrow$ & 0.29 & $\uparrow$ & -0.79 & $\downarrow$ \\
\hline \multicolumn{7}{|c|}{ * \%95 güven aralığında önemli eğilim } \\
\hline & $\uparrow$ Artma Yönu & de Eğilim & & & na Yönünde E & \\
\hline
\end{tabular}


yağıș serileri ile yaptığı eğilim analizinden elde edilmiștir. Söz konusu çalıșmada, zamansal mekânsal farklııklar olmakla beraber Türkiye genelinde yağıșlarda azalma eğilimi görülmüștür. Önol ve Semazzi, (2006) yaptıkları bir çalıșmada, Ege ve Akdeniz kıyılarında yağıșların azalmakta olduğu belirtmișlerdir. Cengil (2009) doktora çalıșmasında, bu çalıșmayı destekleyen eğilimler bulmuștur. Buna göre Denizli'de sıcaklık açısından eğilimde, sürekli bir artıș olmasına rağmen bu artıșın kıș sıcaklıklarında istatistiki olarak önemli olmadığı, ancak yaz sıcaklıklarında önemli olduğu görülmektedir. Yağıșlar açısından, yıllık toplam yağıșlarda azalma eğilimi olmasına rağmen bu eğilim istatistiki olarak önemsiz bulunmuștur.

Bununla birlikte Mann Kendall'a tabi tutulan Aydın Koçarlı AGi verilerinde Temmuz ve Ağustos ayı hariç tüm aylarda azalma eğilimi görülürken, Șubat-Haziran arası ve Aralık aylarında, \%5 anlamllık seviyesinde oldukça belirgin azalma eğilimi göze çarpmaktadır. Yine Denizli Küçüksu AGi verilerinin Z testi sonuçları ise akım verileri yılın tüm aylarında anlamlı azalma eğilimini göstermektedir (Çizelge 4). Özkul ve ark., (2008) ile Durdu (2010)', Büyük Menderes Havzası akımlarında istatistiksel olarak anlamlı bir azalma eğilimi olduğunu ifade ettikleri çalıșmalarıyla araștırmamızın sonuçlarını desteklemektedir.

\section{SONUC̣LAR}

Bu araștırmada alan olarak Büyük Menderes Havzasının \%75 ini kaplayan Aydın, Denizli ve Ușak illerinde bulunan MGl'lerden yağıș, sıcaklık ve AGi'lerden akım verilerinin uzun yıllar boyunca aylık olarak değișimleri ve eğilimleri incelenmiștir. Buna göre özellikle havza sıcaklığında genel bir artıș eğiliminin olduğu ve bu eğilimin de havzanın ortasında ve kuzeydoğusunda daha belirgin olarak ortaya çıktığı görülmüștür. Bununla birlikteyağıșlarda ise aylara göre değișen hem azalma hem de artma eğilimi görülmekle birlikte Ușak istasyonunda sadece nisan ayında $(\alpha=0.05)$ anlamlı bir eğilim bulunmustur. Denizli istasyonunda sıcaklıklardaki așırı artıș eğilimi ve yağıșlardaki azalma eğiliminin havzadaki akımları azalma yönünde etkilediği görülmektedir. Nitekim havzanın akım eğilimlerini incelediğimizde özellikle havzanın ortasında yer alan Denizli Çürüksu AGi verilerinde istatistiki anlamda önemli bir azalma eğilimi görülmüștür (Çizelge 4). Havzanın batısında yer alan Aydın Koçarlı AGi verilerinde ise genel olarak azalma eğilimi dikkat çekmektedir. Sıcaklık, yağıș ve akım verilerinin bu eğilimleri değerlendirildiğinde havzanın orta kısmında görülen sıcaklıklardaki artıș yağıșlardaki azalıș ve akımlardaki belirgin azalıș eğiliminin bölgeyi kuraklık tehlikesiyle yüz yüze getirmesi muhtemeldir.

Çizelge 4. Uzun Yıllar Aylık Toplam Akım Verilerinin Eğilim Sonuçları

Table 4. Trend Results of Monthly Average Streamflow Data for Many Years

\begin{tabular}{|c|c|c|c|c|}
\hline \multirow{5}{*}{ Aylar } & \multicolumn{3}{|c|}{ Akım } & \multirow[b]{2}{*}{ Aydın/Koçarlı AGi } \\
\hline & İstasyon Adı: & Denizli/Çürüksu AGi & İstasyon Adı: & \\
\hline & İstasyon No: & D07A059 & İstasyon No: & D07A062 \\
\hline & Veri Aralığı: & $1985-2015$ & Veri Aralığı: & $1968-2015$ \\
\hline & Test Z & Eğilim & Test Z & Eğilim \\
\hline 1 & -3.17 & ${ }^{\star} \downarrow$ & -1.81 & $\downarrow$ \\
\hline 2 & -3.04 & $\star \downarrow$ & -2.63 & $\star \downarrow$ \\
\hline 3 & -3.68 & $\star \downarrow$ & -3.53 & $\star \downarrow$ \\
\hline 4 & -2.71 & $\star \downarrow$ & -2.25 & $* \downarrow$ \\
\hline 5 & -3.22 & ${ }^{\star} \downarrow$ & -2.68 & $\star \downarrow$ \\
\hline 6 & -3.97 & $\star \downarrow$ & -3.75 & $\star \downarrow$ \\
\hline 7 & -2.11 & $\star \downarrow$ & 1.27 & $\uparrow$ \\
\hline 8 & -2.81 & ${ }^{\star} \downarrow$ & 2.06 & $* \uparrow$ \\
\hline 9 & -3.85 & $\star \downarrow$ & -1.38 & $\downarrow$ \\
\hline 10 & -3.89 & $\star \downarrow$ & -1.56 & $\downarrow$ \\
\hline 11 & -3.44 & ${ }^{\star} \downarrow$ & -1.43 & $\downarrow$ \\
\hline 12 & -3.42 & ${ }^{\star} \downarrow$ & -2.30 & ${ }^{\star} \downarrow$ \\
\hline \multicolumn{5}{|c|}{ * \%95 güven aralığında önemli eğilim } \\
\hline \multicolumn{3}{|c|}{ ^ Artma Yönünde Eğilim } & \multicolumn{2}{|c|}{$\downarrow$ Azalma Yönünde Eğilim } \\
\hline
\end{tabular}


Yine havzanın batısında kalan Aydın istasyonunda görülen eğilimler bölgede bașta su kaynakları olmak üzere, havza ekonomisinde önemli bir yer tutan tarımsal faaliyetleri olumsuz yönde etkilemesi olasıdır. Sonuc olarak havzanın \%44'ünün tarım alanı olduğu ve tarımsal faaliyetlerin en çok Aydın ve Denizli illerinde yapıldığı düșünüldüğünde (Anonim, $2016)$ bu çalıșmadan elde edilen sonuçlar, önlem alınmadığı takdirde, su kaynaklarının ve dolayısıyla tarımsal faaliyetlerin tehdit altında olduğunu göstermektedir.

\section{KAYNAKLAR}

Anonim (2010). Büyük Menderes Havza kirlilik eylem planı, T.C. C.evre Șehircilik ve Orman Bakanlığı. https://webdosya.csb. gov.tr/.

Anonim (2016). Büyük Menderes Havzası Kirlilik Önleme Eylem Planı, T.C. Çevre ve Șehircilik Bakanlığı Cevre Yönetimi Genel Müdürlüğü, Ekim 2016. https://webdosya.csb.gov.tr/ csb/dokumanlar/cygm0013.pdf

Bahadır M (2011). Kızılırmak Nehri akım değișmelerinin istatistiksel analizi. Turkish Studies-International Periodical For The Languages, Literature and History of Turkish or Turkic, Volume 6/3, 1339-1356.

Burn DH, Elnur MAH (2002). Detection of hydrologic trends and variability. Journal of Hydrology, 255, 107-122.

Cengil B (2009). İklim değișiminin Büyük Menderes Havzasında zeytin yetiștirme alanları üzerine etkisi. Ege Üniversitesi fen bilimleri enstitüsü, Doktora Tezi, İzmir.

Cengiz TM, Kahya E (2006). Türkiye göl su seviyelerinin eğilim ve harmonik analizi, ITÜ Dergisi. 5 (3) 2: 215-224.

Chaponniere A, Smakhtin $\vee(2006)$. A review of climate change scenarios and preliminary rainfall trend analysis in the Oum Er Rbia Basin, Morocco. IWMI, Working Paper 110 , Drought Series: Paper 8, Colombo, Sri Lanka.

Çakmak Ö, Baran T (2015). Büyük Menderes Havzas yağıșlarında eğilim analizi. 4. Su Yapıları Sempozyumu $419-427$.

Durdu ÖF (2010). Effects of climate change on water resources of the Büyük Menderes River Basin, Western Turkey. Turk J. Agric For, 34, 319-332, TÜBITAK.

Erdoğan F (1989). Türkiye'de yaygın kuraklık. Meteoroloji Mühendisleri Odası Bülteni 2:1-4.

İçă̆a Y (1994). Analysis of trends in water quality using nonparametric methods. Yüksek Lisans Tezi, Fen Bilimleri Enstitüsü, İzmir.

Kadıoğlu M (1997). Trends in surface air temperature data over Turkey. Int. J. Climatol., 17: 51 1-520.

Kahya E, Kalayci S (2004). Trend analysis of streamflow in Turkey. Journal of Hydrology, 289, 128-144.

Kalaycı S, Kahya E (1998). Susurluk Havzası nehirlerinde su kalitesi trendlerinin belirlenmesi. Journal of Engineering and Environmental Science.

Koçman A, Ișık Ș, Mutluer M (1996). Ege ovalarında yağıș değișkenliği ve kuraklık sorunu. Ege Coğrafya Dergisi, 8, 25-36.
Kosif K (2001). Samsun ilinde iklim trendleri. DSi Teknik Bülteni, Cilt 98, Sayfa 3-13.

Önol B, Semazzi FHM (2006). Regionalization of climate change simulations over the Eastern Mediterranean. American Meteorological Society.

Özfidaner M (2007). Türkiye yağıș verilerinin trend analizi ve nehir akımları üzerine etkisi. Cukurova Üniversitesi Fen Bilimleri Enstitüsü, Yüksek Lisans Tezi (Basılmamıș), 73 s., Adana.

Özkul S, Fıstıkoğlu O, Harmancıoğlu N (2008). İklim değișikliğinin su kaynaklarına etkisinin Büyük Menderes ve Gediz havzaları örneğinde değerlendirilmesi. TMMOB 2. Su Politikaları Kongresi Bildiriler Kitabı, 309-322.

Özkul S (2009). Assessment of climate change effects in Aegean River basins: the case of Gediz and Buyuk Menderes Basins. Climatic Change, 97: 253283.

Özel N (2004). Türkiye'deki nehir akımları aylık verilerinin parametrik olmayan trend analizi. Yüksek Lisans Tezi, SÜ Fen Bilimleri Enstitüsü.

Partal T, Kahya E (2006). Trend analysis in Turkish precipitation data. Hydrological Processes, 20: 2011 1- 2026

Sütgibi S (2009). Büyük Menderes havzasının sıcaklık, yağıș ve akım değerlerindeki değișimler ve eğilimler. Marmara Coğrafya Dergisi, 31, 398-414.

Toros H (1993). Klimatolojik serilerden Türkiye genelinde trend analizi. Yüksek Lisans Tezi, İTÜ Fen Bilimleri Enstitüsü, İstanbul.

Türkes M (1996). Spatial and temporal analysis of annual rainfall variations in Turkey. International Journal of Climatology, 16, 1057-1076.

Türkeș M, Koç T, Sariș F (2009). Spatiotemporal variability of precipitation total series over Turkey. International Journal of Climatology, 29, 1056-1074.

Türkeș M, Deniz ZA (2011). Güney Marmara bölümü'nün (Kuzey Batı Anadolu) Klimatolojisi ile yağıș ve akım dizelerinde gözlenen değișimler ve eğilimler. Uluslararası İnsan Bilimleri Dergisi, 8/1, 1579-1600.

Yeșilırmak E, Akçay S, Dağdelen N (2011). Büyük Menderes havzasında yıllık toplam yağıșların zamansal değișimleri. ADÜ Ziraat Fakültesi Dergisi, 8(1): 37 - 46.

Yıldırım YE, Türkeș M, Tekiner M (2004). Time-Series analysis of long-term variations in stream-flow data of some stream-flow stations over the Gediz Basin and in precipitation of the Akhisar Station. Pakistan Journal of Biological Sciences, 7: $17-24$

Yue YS, Zou S, Whittemore D (1993). Non parametric trend analysis of water quality data of rivers in Kansas. Journal of Hydrology, 150, 61-80.

Yue S, Wang CY (2002). Regional streamflow trend detection with consideration of both temporal and spatial correlation. International Journal of Climatology, 22(8):933946.

Zhang X, Harvey KD, Hoggy WD, Yuzyk TR (2001). Trends in Canadian streamflow. Water Resour. Res., 37,4: 987-998. 